\title{
Age-related cellular and physiological reactions to hypoxia and hyperthermia in marine mussels
}

\author{
Lisa M. Hole ${ }^{1,2, *}$, Michael N. Moore ${ }^{1}$, Denis Bellamy ${ }^{2}$ \\ ${ }^{1}$ Plymouth Marine Laboratory (NERC), Citadel Hill, Plymouth PL1 2PB, United Kingdom \\ ${ }^{2}$ School of Pure and Applied Biology, University of Wales College of Cardiff, PO Box 915, Cardiff CF1 3TL, United Kingdom
}

\begin{abstract}
Marine mussels Mytilus edulis (L.) from 3 different age/size groups were exposed for $24 \mathrm{~h}$ to combined hypoxia and hyperthermia $\left(28 \pm 1^{\circ} \mathrm{C}\right)$ and subsequently reimmersed in seawater at $10 \pm$ $1^{\circ} \mathrm{C}$. Exposure to the physical stressor induced lysosomal destabilisation and enlargement in the digestive cells of mussels of all ages. Recovery of lysosomal integrity was demonstrated after 24 h in seawater by the youngest mussels ( $2-4$ yr) only. Levels of unsaturated neutral lipids increased in all mussels following exposure and was associated with enlarged lysosomes. No consistent pattern or significant change was observed in lipid levels in mussels of any age during the recovery period. Levels of lipofuscin (stress pigment) in mussels exposed to hypoxia and hyperthermia and in those subsequently reimmersed in seawater did not follow any consistent pattern, but were generally much higher in the youngest mussels than in the older age groups. Recovery of metabolic rates to control levels was observed $12 \mathrm{~h}$ after reimmersion in seawater in the youngest mussels only. Metabolic rates of the 6-8 and $\geq 10$ yr mussels remained elevated relative to the controls after this time. These findings indicate that the stress reaction is independent of age but that the potential for recovery of lysosomal integrity and metabolic rate is age-related.
\end{abstract}

KEY WORDS: Mussels - Age-related - Lysosomes Lipid - Lipofuscin - Metabolic rate - Autophagy Hypoxia Hyperthermia

\section{INTRODUCTION}

Few studies have examined whether a mussel's age influences its susceptibility to stress and its ability to recover. This is an important consideration as older mussels produce disproportionately more gametes than younger mussels and an age-related decline in capacity for recovery could ultimately reduce the viability of the population. Any age-related differences in stress responses and recovery should also be taken into account in studies involving mussels as environmental sentinels

Several studies have shown that cellular changes, such as lysosomal destabilisation, in mussels are correlated with physiological changes, such as reduction in scope for growth (e.g. Bayne et al. 1979, Moore et al.

\footnotetext{
- Present address: Ministry of Agriculture, Fisheries and Food Room 309, Nobel House, 17 Smith Square, London SW1P 3JR, United Kingdom
}

1987). A decline in scope for growth signifies impaired growth efficiency (Bayne et al. 1981) and an inevitable result will be smaller individuals. As mussels grow in size the speed with which resources are allocated to gametogenesis increases. Reduced growth efficiency therefore lowers the fitness of the individual by indirectly reducing fecundity. In this way cellular responses can be linked to the fitness of the individual and ultimately to the population.

We have shown previously that mussels exposed to copper exhibit cellular responses that are independent of the mussel's age but that older mussels have a reduced capacity for recovery (Hole et al. 1992, 1993). In this experiment we used mussels from the same population and of the same 3 age/size groups to investigate the influence of age on mussels' susceptibility to a physical stressor and their ability to recover.

The physical stressor to which mussels were subjected was 24 h hypoxia (mean oxygen tension $=2 \mathrm{~mm}$ $\mathrm{Hg})$ and hyperthermia $\left(28^{\circ} \mathrm{C}\right)$. While intertidal mussels 
can experience oxygen deprivation and hyperthermia at low tide on a warm day when they close their valves to prevent desiccation, the conditions used in this experiment were close to the upper limit of their environmental and physiological range (Bayne et al. 1976) and were chosen to elicit a measurable cellular response.

Hyperthermia (25 and $28^{\circ} \mathrm{C}$ ) has been shown to induce marked lysosomal destabilisation in mussels (Moore 1976). The effects of exposure to prolonged hypoxia ( $48 \mathrm{~h}$ ) on lysosomal membrane stability appear to be enhanced by simultaneous exposure to elevated temperature $\left(20^{\circ} \mathrm{C}\right.$ ) (Moore et al. 1979). Restoration of lysosomal integrity was observed upon the mussels' return to seawater at $10^{\circ} \mathrm{C}$.

Moore \& Viarengo (1987) have demonstrated that lysosomal destabilisation in mussels' digestive gland cells is related directly to enhanced protein catabolism and is indicative of autophagy. Proteolytic enzymes within the lysosomes degrade intracellular proteins and autophagocytosed organelles. Induced fatty acid change results in enrichment of unsaturated neutral lipids, initially in the cytosol, and then in the lysosomes (Moore 1988). The lipids may subsequently be peroxidised to yield malondialdehyde (MDA). Elevated levels of lipid (Capuzzo \& Leavitt 1988, Lowe 1988, Moore 1988, Hole et al. 1993) and lipofuscin (Moore 1988) have been found associated with fragile, enlarged lysosomes in the digestive cells of mussels. A marked decline in lipid peroxidation has been detected in mussels of different ages in response to $24 \mathrm{~h}$ nitrogen exposure at $28^{\circ} \mathrm{C}$; this trend was reversed in older mussels ( $\geq 10 \mathrm{yr}$ ) following reimmersion in seawater at $10^{\circ} \mathrm{C}$ for 24 h (Viarengo et al. 1989). However, lipid peroxidation was evaluated as MDA concentration and not as lipofuscin, which is believed to be formed by the cross-linking of MDA with amine groups in autophagocytosed lipoprotein membranes, and might therefore appear in the cells at a later stage.

In this experiment we also examined the effect of age on the metabolic rate (rate of oxygen consumption) of mussels exposed to the physical stressor. Mussel size and exposure temperature are often considered to be the most important factors that can affect their metabolic rate (Bayne \& Newell 1983). Smaller (younger) mussels generally have a higher metabolic rate, which they are less able to regulate under hypoxic conditions, than larger (older) mussels. The effect of exposure temperature on metabolic rate has been shown to be more pronounced when mussels are simultaneously exposed to air, as compensatory adjustments in oxygen consumption rates are precluded under these conditions (Bayne \& Newell 1983). Zandee et al. (1986) found that mussels' rates of oxygen consumption are elevated following reimmersion in seawater as mussels attempt to repay the 'oxygen debt' associated with the accumulation of end products of anaerobic metabolism. The extent of the oxygen debt is related to the duration of exposure to air and is greater at elevated temperatures (Widdows et al. 1979).

Whilst it has not, as yet, been demonstrated in mussels, it is thought that increased oxygen consumption and the consequent elevated oxygen flux may result in an elevation of peroxidative processes (Viarengo et al. 1989, Winston et al. 1991). The normal fate of molecular oxygen in eukaryotic organisms is tetravalent reduction to water, coupled to the oxidative phosphorylation of ADP to ATP. Increased oxygen consumption leads to an enhanced flux of oxygen in the tissues, which saturates this mechanism; this leads, in turn, to partial (univalent) reduction of oxygen to form the superoxide radical, $\mathrm{O}_{2}{ }^{-}$, which can dismutate to hydrogen peroxide. Hydrogen peroxide can serve as a precursor of the hydroxyl radical, $\mathrm{OH}$. The in vitro potential for oxyradical generation, the presence of free radical scavengers and specific antioxidant enzymes, and the existence of lipid peroxide and other products of oxidative damage in mussel tissues, all indicate that oxyradical generation occurs in vivo in molluscs (Livingstone et al. 1990).

This study was conducted to investigate the influence of mussel age on lysosomal cytochemical parameters in digestive gland cells and on the metabolic rate of mussels exposed to combined hypoxia and hyperthermia and subsequently reimmersed in seawater at ambient temperature.

\section{MATERIALS AND METHODS}

Experimental details. Mussels of the 3 age groups $2-4,6-8$ and $\geq 10$ yr were collected from Beggar's Island near Plymouth (UK) in June 1987. They were selected on the basis of a von Bertalanffy growth curve (a revised version of the curve by Bayne \& Worrall 1980) relating shell length to age for this population. The mussels were cleaned and acclimated for a minimum of $8 \mathrm{~d}$ in a $20 \mathrm{l}$ polypropylene tank through which aerated, filtered, recirculating seawater at $10 \pm 1^{\circ} \mathrm{C}$ and $32 \pm 1 \%$ salinity flowed continuously. They were fed continuously on the alga Phaeodactylum tricornutum during the acclimation period $>30 \mathrm{mg}$ mussel $^{-1}$ $\mathrm{d}^{-1}$ based on a $6-8$ yr mussel).

The experiment was conducted as described below using mussels of 1 age group at a time. Ten mussels were removed from the seawater immediately prior to the start of the experiment: these represented the controls. Experimental mussels were placed in a $5 \mathrm{l}$ glass respirometer into which nitrogen gas was pumped for 5 min to displace the air. The respirometer was then 
sealed, clamped, and placed in a water bath at $28^{\circ} \mathrm{C}$. An oxygen electrode inserted through the lid of the respirometer was used to check that the conditions remained hypoxic throughout the experiment (mean oxygen tension $=2 \mathrm{~mm} \mathrm{Hg}$ ). After $24 \mathrm{~h} 10$ mussels were sacrificed and the remainder were transferred to seawater at $10^{\circ} \mathrm{C}$, fed as before and, in groups of 10 , removed 3, 6, 12 and 24 h later.

Cytochemical determinations. Portions ( 3 to $4 \mathrm{~mm}^{3}$ ) of digestive glands of all the mussels sampled were removed for cytochemical determination of lysosomal membrane stability and levels of unsaturated neutral lipids and lipofuscin. These tissues were placed on aluminium chucks, quenched in hexane $\left(-70^{\circ} \mathrm{C}\right)$, doublewrapped in parafilm and stored at $-70^{\circ} \mathrm{C}$.

Lysosomal stability: Cryostat sections $(10 \mu \mathrm{m})$ of digestive glands of all the mussels were reacted for lysosomal membrane stability based on the cytochemical latency of $\beta$ - $\mathrm{N}$-acetylhexosaminidase (NAH), as described previously (Moore 1976, 1988). Twelve assessments of labilisation period were made in duplicate sections for each mussel using a Zeiss microscope $(\times 400)$. The results were tested for significant differences at the $5 \%$ level using the non-parametric Friedman's and Kruskal-Wallis tests.

Unsaturated neutral lipids: Unsaturated neutral lipid levels were determined in $10 \mu \mathrm{m}$ fixed cryostat sections of digestive glands using the Oil Red O reaction (Bancroft 1967). Twenty measurements per mussel (10 per duplicate section) were made at random in the apical region of the digestive tubules at $530 \mathrm{~nm}$, using a Vickers M85 scanning integrating microdensitometer $\left(\times 400 ;\right.$ mask area $=130 \mu^{2}$, measuring beam diameter $=0.5 \mu \mathrm{m}$, slit width $=30 \mathrm{j}$. The results were logarithmically transformed to correct for unequal variances and analysed using a 2 -way analysis of variance at the $5 \%$ level.

Lipofuscin: Fixed cryostat sections (10 $\mu \mathrm{m})$ of digestive glands of control ( $0 \mathrm{~d}$ ) and experimental mussels were stained for lipofuscin using the Schmorl reaction (Bancroft 1967) and stored in the dark until measurements were made. Twenty measurements per mussel (10 per duplicate section) were made at random in the digestive tubules at $660 \mathrm{~nm}$, using a Vickers M85 scanning integrating microdensitometer $\left(\times 400\right.$, mask area $=130 \mu \mathrm{m}^{2}$, measuring beam diameter $=0.5 \mu \mathrm{m}$, slit width $=60$ ) . The results were analysed using a 2-way analysis of variance at the $5 \%$ level.

Rates of oxygen consumption. Oxygen consumption rates of control mussels and of experimental mussels sampled $12 \mathrm{~h}$ after reimmersion in seawater were determined according to the method described by Widdows $\&$
Shick (1985). The rates of oxygen consumption of the mussels were corrected to the standard body mass of that particular age group and were expressed as $\mathrm{ml} \mathrm{O}_{2}$ $g^{-1} h^{-1}$. The data were $\log _{10}$ transformed (as the standard deviations of these data were proportional to the means and the effects were multiplicative rather than additive) and tested for significant differences at the $5 \%$ level using a 2 -way analysis of variance.

\section{RESULTS}

\section{Lysosomal membrane stability}

The labilisation periods of lysosomal NAH in the digestive cells of the $2-4$ and $\geq 10$ yr control mussels were similar and were lower than that of the $6-8 \mathrm{yr}$ controls, although this difference was not significant ( $p>0.05$; Fig. 1). Exposure to hypoxia $(24 \mathrm{~h})$ at $28^{\circ} \mathrm{C}$ caused a dramatic decline in the latency of NAH ( $\mathrm{p} \leq$ 0.05, Fig. 1) and an enlargement of the lysosomes in the digestive cells of all mussels. The latent activity of $\mathrm{NAH}$ in all the mussels remained unchanged even $12 \mathrm{~h}$ after they had been reimmersed in seawater. After $24 \mathrm{~h}$, however, NAH latency in the youngest mussels increased significantly $(p \leq 0.05)$, though not to the control levels, and the lysosomes resumed their normal appearance. Latent NAH activity in the 6-8 and $\geq 10$ yr mussels was still depressed and their lysosomes remained enlarged.

\section{Unsaturated neutral lipids}

Unsaturated neutral lipids were present in the digestive cells of the control mussels as droplets. The levels

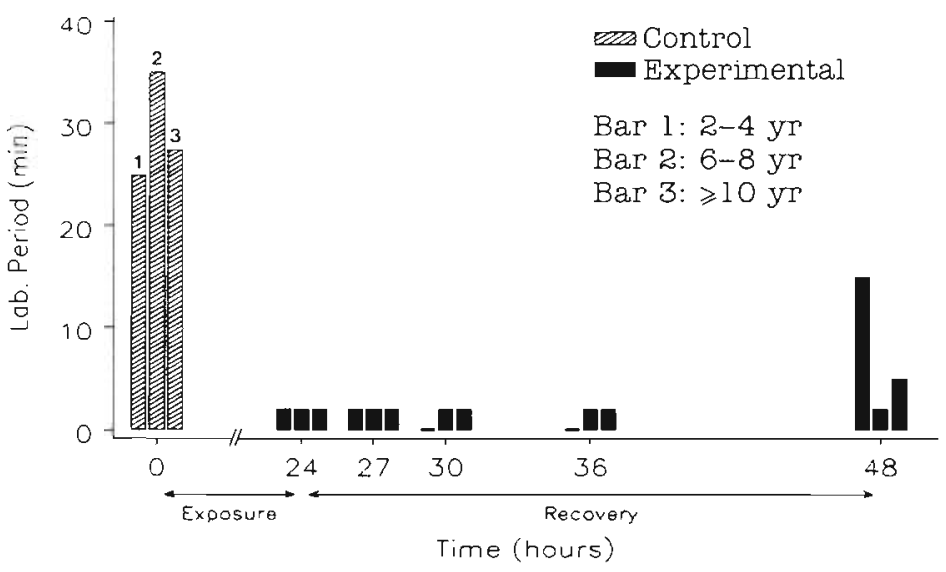

Fig. 1. Mytilus edulis. Effects of exposure to $24 \mathrm{~h}$ hypoxia at $28^{\circ} \mathrm{C}$ and subsequent immersion on the labilisation period of latent $\beta$ - $\mathrm{N}$-acetylhexosaminidase in the digestive cell lysosomes of mussels of different ages. Medians ( $\mathrm{n}=10$ ) are shown 


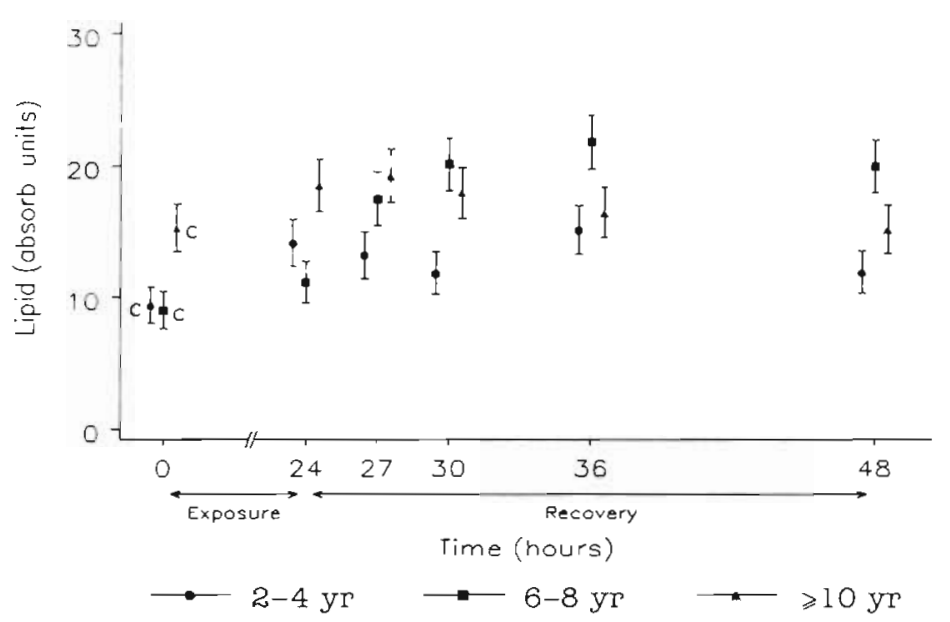

Fig. 2. Mytilus edulis. Effects of exposure to $24 \mathrm{~h}$ hypoxia at $28^{\circ} \mathrm{C}$ and subsequent immersion on the unsaturated neutral lipid content of the digestive cells of mussels of different ages. Means ( $\mathrm{n}=10) \pm 95 \%$ confidence intervals are shown. C: controls

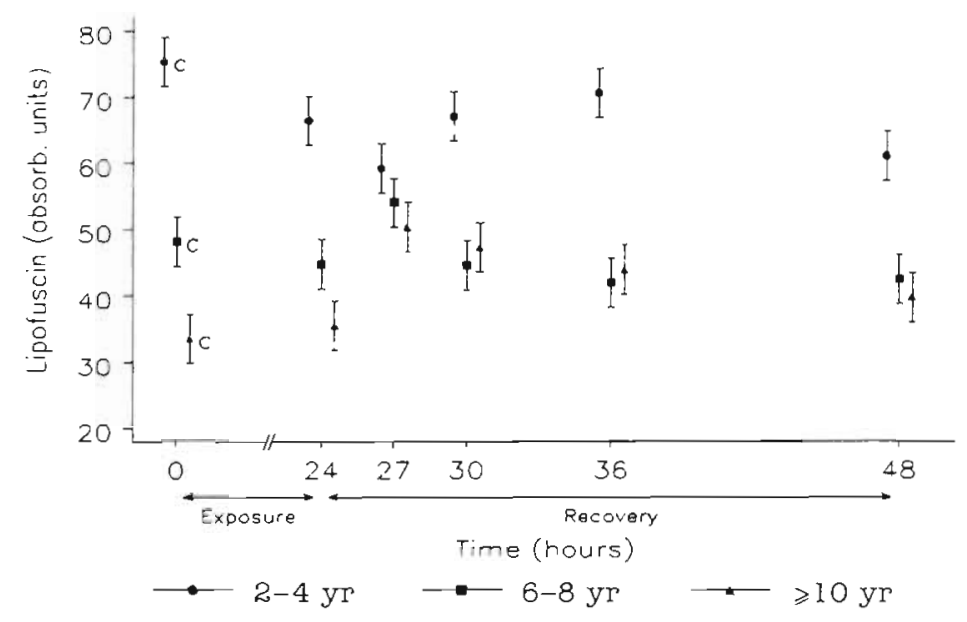

Fig. 3. Mytilus edulis. Effects of exposure to $24 \mathrm{~h}$ hypoxia at $28^{\circ} \mathrm{C}$ and subsequent immersion on the lipofuscin content of the digestive cells of mussels of different ages. Means $(n=10) \pm 95 \%$ confidence intervals are shown. C: controls

of lipids in the digestive glands of the $\geq 10 \mathrm{yr}$ control mussels were higher than those of the $2-4$ and $6-8 \mathrm{yr}$ controls $(p>0.05)$ whose lipid levels were similar (Fig. 2). Exposure to hypoxia and hyperthermia caused an increase in lipid levels in all mussels $(p>0.05$; Fig. 2). The lipids were associated with enlarged lysosomes and the number of cytoplasmic lipid droplets increased at this time. During the period of recovery in seawater, lipid levels in the youngest and oldest mussels fluctuated slightly. In contrast, lipid levels in the $6-8$ yr mussels increased markedly following $3 \mathrm{~h}$ in seawater $(p \leq 0.05)$ and were significantly higher than those of the $2-4$ yr individuals after $6 \mathrm{~h}$ in seawater $(p \leq$
$0.05)$. The elevated levels of lipid in these individuals persisted throughout the recovery period, such that they were still much higher than that of the controls after $24 \mathrm{~h}$ ( $\mathrm{p} \leq 0.05$ ) The lipid level in these mussels was aiso much greater than that of the youngest individuals at this time $(p \leq 0.05)$.

\section{Lipofuscin}

Lipofuscin was localised in the secondary and tertiary lysosomes in the digestive cells of the control mussels. The levels of lipofuscin in the control mussels differed markedly, being much higher in the youngest than in the oldest mussels ( $p \leq 0.05$; Fig. 3). Lipofuscin levels in the youngest mussels declined sharply upon exposure to hypoxia at $28^{\circ} \mathrm{C}$ and $3 \mathrm{~h}$ after reimmersion in seawater ( $p \leq 0.05$; Fig. 3 ). By contrast, levels of lipofuscin in the digestive cells of the 6-8 and $\geq 10$ yr mussels remained unchanged after exposure to hypoxia and hyperthermia but rose dramatically $3 \mathrm{~h}$ after reimmersion in seawater $(p \leq 0.05)$. Following $6 \mathrm{~h}$ in seawater lipofuscin levels in the youngest mussels increased slightly ( $p>0.05)$, while those of the $6-8$ and $\geq 10$ yr individuals showed a downward trend. For the remainder of the recovery period, the lipofuscin levels in all mussels were relatively stable. The digestive cells of the youngest mussels contained significantly more lipofuscin $(p \leq 0.05)$ than those of the other age groups at all times except $3 \mathrm{~h}$ after reimmersion in seawater.

\section{Rate of oxygen consumption}

The oxygen consumption rates of all the control mussels were similar (Table 1). The metabolic rates of the $6-8$ and $\geq 10$ yr mussels

Table 1. Mytilus edulis. Age-related differences (means $\pm \mathrm{SD}$ $\mathrm{n}=10)$ in the rates of oxygen consumption $\left(\mathrm{ml} \mathrm{O} \mathrm{O}^{-1} \mathrm{~h}^{-1}\right)$ of control mussels and those exposed to hypoxia $(24 \mathrm{~h})$ at $28^{\circ} \mathrm{C}$ and subsequently reimmersed in seawater at $10^{\circ} \mathrm{C}$ for $12 \mathrm{~h}$ (experimental)

\begin{tabular}{|cccc|}
\hline & $2-4 \mathrm{yr}$ & $6-8 \mathrm{yr}$ & $\geq 10 \mathrm{yr}$ \\
\hline Control $(0 \mathrm{~h})$ & 0.273 & 0.220 & 0.233 \\
& $( \pm 0.069)$ & $( \pm 0.048)$ & $( \pm 0.059)$ \\
Experimental & 0.275 & 0.359 & 0.313 \\
& $( \pm 0.103)$ & $( \pm 0.068)$ & $( \pm 0.074)$ \\
\hline
\end{tabular}


remained elevated $(63 \%$ and $34 \%$ respectively relative to the controls) $12 \mathrm{~h}$ after the mussels had been reimmersed in seawater following exposure ( $p \leq 0.05)$. The metabolic rate of the youngest experimental mussels was similar to that of the controls.

\section{DISCUSSION}

Nitrogen exposure $(24 \mathrm{~h})$ at $28^{\circ} \mathrm{C}$ evoked a significant enlargement and destabilisation of the lysosomes in the digestive cells of mussels of all ages. These changes are indicative of autophagy and have been observed previously in the digestive cells of mussels exposed to air for $48 \mathrm{~h}$ at $20^{\circ} \mathrm{C}$ (Moore et al. 1979). The labilisation period of $\mathrm{NAH}$ remained reduced in all mussels even $12 \mathrm{~h}$ after they had been reimmersed in seawater. Partial recovery of lysosomal integrity was evident in the $2-4$ yr mussels after $24 \mathrm{~h}$ in seawater, while the lysosomes of the $6-8$ and $\geq 10$ yr mussels remained destabilised and enlarged.

The accumulation of unsaturated neutral lipids in all mussels after $24 \mathrm{~h}$ exposure and its association with enlarged lysosomes in the digestive cells lend further support to the evidence that autophagy has been induced in these cells. Lowe (1988) and Moore (1988) reported similar stress-induced changes in the digestive cells of mussels and considered these to be indicative of autophagy. The levels of lipid in the youngest and oldest mussels did not exhibit any marked changes during the recovery period. The significant increase in lipid content in the 6-8 yr mussels following $3 \mathrm{~h}$ immersion in seawater indicates an intensified stress response, which persisted throughout the recovery period and was much higher than that observed in the youngest mussels. This is consistent with the persistence of lysosomal enlargement and instability.

Lipofuscin levels were highest in the youngest mussels throughout the experiment. We have reported similar findings previously (Hole et al. 1993). This might seem surprising as lipofuscin has often been reported to increase with age and has therefore been dubbed an 'age pigment'. Several studies have demonstrated its accumulation in response to stress, whether environmental, dietary or related to disease (Miquel et al. 1977, Sharma \& Manocha 1977). The rate of accumulation of lipofuscin seems to be related directly to the metabolic rate of the organism (Sohal 1981). The hypothesis arising from this observation is that a higher metabolic rate will lead to a greater oxygen flux which might result in an elevation of peroxidative processes (see 'Introduction') and, if unchecked by antioxidants, will induce autophagy and promote the formation of lipofuscin. Youngest mussels have the highest metabolic rate and would, under this hypothe- sis, be expected to have the highest levels of lipofuscin. It is possible that the formation of lipofuscin bears a direct relationship to the rate of protein turnover which might be higher in younger mussels, as it is in fish (Fauconneau 1985). Lipofuscin accumulation is generally considered to be indicative of autophagy (Davies 1983). The decline in the lipofuscin content of the digestive cells of the youngest mussels after 24 h exposure implies a loss by exocytosis in these mussels, which returns to normal after $6 \mathrm{~h}$ in seawater. The increase in lipofuscin levels in the $6-8$ and $\geq 10$ yr mussels $3 \mathrm{~h}$ after reimmersion in seawater is consistent with the autophagic reactions occurring at this time and possibly with increased peroxidative processes as a result of the enhanced oxygen consumption which persisted even $12 \mathrm{~h}$ after the mussels had been reimmersed in seawater (see 'Introduction'). Its accumulation in older mussels only might also be related to the lower levels of the antioxidants, glutathione (GSH) and vitamin $E$, detected in the digestive glands of older mussels relative to those of younger ones (Viarengo et al. 1989), thus reducing the intracellular protective capability of older mussels.

In conclusion, these results indicate that exposure to combined hypoxia and hyperthermia induces autophagy in the digestive gland cells of mussels of all ages. However, there was an age-related decline in the mussels' ability to restore lysosomal integrity and basal oxygen consumption following their return to seawater This resulted in continued catabolism of cellular constituents in the $6-8$ and $\geq 10$ yr mussels. These results confirm the findings of a previous study in which mussels from the same population and the same 3 age groups were exposed to copper (Hole et al. 1993) and demonstrate that older mussels are more susceptible to hypoxia and hyperthermia than younger ones This should be taken into account in general ecophysiological studies and when mussels are used as environmental sentinels.

Acknowledgements. This work was supported in part by a NERC postgraduate studentship grant to L.M.H. and a NATO Collaborative Research Grant (R.0108/88) to M.N.M., A. Viarengo and $G$. Winston.

\section{LITERATURE CITED}

Bancroft JD (1967) An introduction to histochemical technique. Butterworths, London

Bayne BL, Clarke KR, Moore MN (1981) Some practical considerations in the measurement of pollution effects on bivalve molluscs, and some possible ecological consequences. Aquat Toxicol 1:159-174

Bayne BL, Moore MN, Widdows J, Livingstone DR, Salkeld P (1979) Measurement of the responses of individuals to environmental stress and pollution: studies with bivalve molluscs. Phil Trans R Soc Lond B 286:562-581 
Bayne BL, Newell RC (1983) Physiological energetics of marine molluscs. In: Saleuddin ASM, Wilbur KM (eds) The Mollusca, Vol 4. Academic Press, New York, p 407-515

Bayne BL. Thompson RJ. Widdows J (1976) Physiology: I. In: Bayne BL (ed) Marine mussels: their ecology and physiology. IBP 10. Cambridge University Press, Cambridge

Bayne BL, Worrall CM (1980) Growth and production of mussels Mytilus edulis from two populations. Mar Ecol Prog Ser 3:317-328

Capuzzo JM. Leavitt DF (1988) Lipid composition of the digestive glands of Mytilus edulis and Carcinus maenas in response to pollutant gradients. Mar Ecol Prog Ser 46: $139-145$

Davies I (1983) Ageing. Edward Arnold, London

Fauconneau B (1985) Protein synthesis and protein deposition in fish. In: Cowey CB, Mackie AM, Bell JG (eds) Nutrition and feeding in fish. Academic Press, New York, p 17-46

Hole LM, Moore MN, Bellamy D (1992) Age-related differences in the recovery of lysosomes from stress-induced pathological reactions in marine mussels. Mar environ Res 34:75-80

Hole LM, Moore MN, Bellamy D (1993) Age-related cellular reactions to copper in the marine mussel Mytilus edulis (L.). Mar Ecol Prog Ser 94:175-179

Livingstone DR, Garcia Martinez P, Michel X, Narbonne JF, O'Hara S, Ribera D, Winston GW (1990) Oxyradical production as a pollution-mediated mechanism of toxicity in the common mussel, Mytilus edulis L., and other molluscs. Funct Ecol 4:415-424

Lowe DM (1988) Alterations in cellular structure of Mytilus edulis resulting from exposure to environmental contaminants under field and experimental conditions. Mar Ecol Prog Ser 46:91-100

Miquel J, Oro J, Bensch KG, Johnson JE (1977) Lipofuscin: Fine-structural and biochemical studies. In: Pryor WA (ed) Free radicals in biology, Vol 3. Academic Press, New York, p 133-182

Moore MN (1976) Cytochemical demonstration of latency of lysosomal hydrolases in digestive cells of the common mussel, Mytilus edulis, and changes induced by thermal stress. Cell Tiss Res 175:279-287

This article was submitted to the editor
Moore MN (1988) Cytochemical responses of the Iysosomal system and NADPH-ferrihemoprotein reductase in molluscan digestive cells to environmental and experimental exposure to xenobiotics. Mar Ecol Prog Ser 46:81-89

Moore MN, Livingstone DR, Widdows J, Lowe DM, Pipe RK (1987) Molecular, cellular and physiological effects of oilderived hydrocarbons on molluscs and their use in impact assessment. Phil Trans R Soc Lond B 316:603-623

Moore MN, Lowe DM, Moore SL (1979) Induction of lysosomal destabilisation in marine bivalve molluscs exposed to air. Mar Biol Lett 1:47-57

Moore MN, Viarengo A (1987) Lysosomal membrane fragility and catabolism of cytosolic proteins: evidence for a direct relationship. Experientia 43:320-323

Sharma SP, Manocha SL (1977) Lipofuscin formation in the developing nervous system of squirrel monkeys consequent to maternal dietary protein deficiency during gestation. Mech Age Dev 6:1-14

Sohal RS (1981) Metabolic rate, aging and lipofuscin accumulation. In: Sohal RS (ed) Age pigments. Elsevier/NorthHolland Biomedical Press, Amsterdam, p 303-316

Viarengo A, Pertica M, Canesi L, Accomando R, Mancinelli G, Orunesu $M$ (1989) Lipid peroxidation and level of antioxidant compounds (GSH, vitamin E) in the digestive glands of mussels of three different age groups exposed to anaerobic and aerobic conditions. Mar environ Res 28:291-295

Widdows J, Bayne BL, Livingstone DR, Newell RIE, Donkin P (1979) Physiological and biochemical responses of bivalve molluscs to exposure to air. Comp Biochem Physiol 62A: 301-308

Widdows J, Shick JM (1985) Physiological responses of Mytilus edulis and Cardium edule to aerial exposure. Mar Biol 85:217-232

Winston GW, Moore MN, Straatsburg I, Kirchin M (1991) Decreased stability of digestive cell lysosomes from the common mussel Mytilus edulis L. by in vitro generation of oxygen free radicals. Arch Environ Contam Toxicol 21:401-408

Zandee DI, Holwerda DA, Kluytmans JH, De Zwaan A (1986) Metabolic adaptations to environmental anoxia in the intertidal bivalve mollusc Mytilus edulis L. Neth J Zool 36: $322-343$

Manuscript first received: December 6, 1993

Revised version accepted: February 14, 1995 